\title{
Policies for managing sudden stops ${ }^{*}$
}

\author{
Chokri Zehri ${ }^{1}$
}

\begin{abstract}
Managing capital flows needs an appropriate association of foreign exchange reserves, foreign borrowing, and capital control. These policies are considered as a tool to predict sudden stops (SS). Consequently, this analysis identifies the occurrences of SS for a sample of 200 countries within the period 1985 - 2019. The probability of SS is determined through a logit model. Results suggest that effective management reduces the probability of sudden stops. A spillover risk influence analysis was conducted on the gross domestic product, consumption, investment, and unemployment. The results show harmful impacts on these macroeconomic variables. The findings demonstrate that countries with a satisfactory level of exchange foreign reserves, small foreign borrowing, and initiating capital controls before the occurrence of SS, are less touched by the spillover risk than emergent economies which are more vulnerable than rich economies.
\end{abstract}

Key words: sudden stops, policies, capital flows, debts, reserves, controls

JEL classification: F32, F36, F37

\section{Introduction}

The countries that have received large capital flows can be exposed to diverse risks, specifically when these capitals are badly managed (Eichengreen and Gupta, 2016). One of the most common risks is capital flow sudden stops, reflecting an abrupt stop in inflows. The expected consequence is often exhaustion of exchange reserves and high currency depreciation. To enjoy the advantages of these inflows, developing countries must well manage the accompanying risks (Jeanne and Korinek, 2019).

With the increase in global capital flows, these countries are being faced with a major economic challenge that requires an in-depth study and to be openly

\footnotetext{
* Received: 02-03-2020; accepted: 06-05-2020

1 Assistant Professor of Economics, Prince Sattam Bin Abdulaziz University, College of Sciences and Humanities in Al-Sulail. Department of Business Administration, Saudi Arabia. Scientific affiliation:international financial liberalization, capital controls \& financial crisis. Phone: +966554907434.Fax: +966117822251.E-mail: c.alzhari@psau.edu.sa.
} 
resolved. Numerous analyses look for an ideal approach to accumulate reserves, raise foreign borrowing, and resort to restriction policies using capital controls (Aizenman and Lee, 2007; Hawkins and Turner, 2000 and Zehri and Abdelkarim, 2020). The practice of capital controls is mainly seen after the Asian financial crisis of 1997. This restrictive policy instrument has made it possible to better understand the devastating effects of SS (Ostry, 2012). The interest in the use of capital controls has been resurfaced with more intensity, especially after the recent financial crises of 2008, as a necessary instrument to reduce the risks resulting from financial weakness. Ostry et al. (2010) suggest, dealing with the various macroeconomic risks, that a set of controls on capital movements must be used. These controls are above all effective in conjunction with the holding of a certain level of international reserves. Evidence shows that several economies that have liberalized their financial systems are keen to accumulate foreign exchange reserves. The ideal practice of these three procedures (controls, reserves, and debts) is composed of many studies dealing with administrating capital movements. Simultaneously, these policies are utilized to cope with the main risk of capital inflows, the sudden stops. In the 1990 decade, the reversal flows affecting developing economies were seen as warning signs of a larger crisis, that of 2008. Throughout these reversal flows, economies have less access to the credit market, which caused serious distortions of the current account and which led to heavy recessions.

The study contributed to previous studies by proposing an analytical framework that helps policymakers towards better management of capital flows and ensuring more macro-financial stability. Firstly, we identify periods of sudden stops using a panel of 200 developing and developed countries over the period 1985-2019. Several empirical studies use an analysis of events by monitoring the abrupt evolution of current account and trade balance to detect these periods of sudden stops.

Secondly, the study followed the evolution of macroeconomic aggregates about their values for a period considered normal, to determine some features of sudden stops events. Referring to previous studies, the paper suggests rules that help to determine these SS events (Hutchison and Noy, 2006; Guidotti et al., 2004; Agosin et al., 2019). Regarding sudden stops periods, there are two major policy matters: First, which factors determine the manifestation of this downtime? And second, what impact will these sudden stops have on a country's macroeconomic aggregates? The study targets to give adequate responses to these questions.

The study has contributed to earlier studies by concentrating on the three policies already debated. Foreign exchange reserves, foreign borrowing, and capital controls are the three basic aspects of adequate governance of capital flows, which have an important role in solving this spillover risk. The analysis uses a logit model to determine sudden stops likelihood. 
Thirdly, once we have determined these SS periods as well as their role in increasing the probability of reversal flows, the study will try to determine their impact on the welfare of the economy. These periods were often accompanied by persistent recessions and major macro-financial vulnerabilities, leading to weaker consumption and investment and consequently to significantly lower growth rates (Calvo, Izquierdo and Mejia, 2004). Two major characteristics are specified from the 2008 crisis: a reversal in capital flow and a drop in production (Calvo, 1998). Some studies have analyzed the economic crisis features of countries, which have experienced sudden stops; especially, there has been a decline in the gross domestic product, consumption, and investment, as well as an increase in unemployment (Chari, Kehoe, and McGrattan, 2005; Calvo and Talvi, 2005; Cardarelli, Elekdag, and Kose, 2010). For a larger sample in comparison to previous studies, we try to analyses the adverse evolution of these aggregates. The study targets to prove, in events of SS, the degradation of these aggregates in comparison to the "calm" period. On the other hand, we try to prove that emergent economies are more influenced by SS than developed economies (Calvo, Izquierdo, and Talvi, 2006).

The research hypotheses arising from the previous debate are summarized as follow:

H1: Dates of SS can be determined with exactitude.

$\mathrm{H} 2$ : Our model can determine the probability of SS

H3: The SS have adverse effects on the macroeconomic aggregate.

This study is organized as follows: The next section reviews the empirical literature concerning the prediction of sudden stops and the consequence of sudden stops on economic fundamentals. The third section shows the models' variables and regressions methods. The fourth section displays empirical study in reliance on three goals. Primarily, the analysis identifies the sudden stops periods. Secondary, the analysis investigates the factors of sudden stops probability and highlights the adequate management of capital flows in lowering this probability. Finally, the study highlights the changes in macroeconomic fundamentals through a comparison before and after SS periods. The last two sections (five and six), discusses the consequence of study results and the approaches needed to prevent sudden stop.

\section{Literature review}

Considering the research hypotheses of the study, this section develops the literature review around three components. First, theories discussing the occurrence of SS, second, empirical studies to predict SS and third, the impacts of SS on macroeconomic aggregates. 


\subsection{Theory of sudden stops}

Many theories discussed the occurrence of SS (Calvo, 1988, 1998; Kaminsky and Reinhart, 1999; Cole and Kehoe, 2000; Mendoza, 2006). Models have been built to clarify policymakers' decision to fail on its credit repayment or an external lender's agreement to borrow, generally, the impacts of default are exogenous. Contrary, another row of studies has concentrated on the impacts of sudden stops, taking the SS as provided. Chari et al. (2005), Cook and Devereux (2006), and Meza and Quintin (2007) suppose that sudden stop is exogenous and they analyze their impacts on macroeconomic fundamentals. To hold reserves is an exterior balance sheet action monitoring by the central bank where foreign borrowing is usually provided to the public sector for many economies (Alberola, Erce and Serena, 2016). The cost of borrowing debt is higher than the return of holding reserves which makes their accumulation an unprofitable decision (Bussiere et al., 2013). The common guarantee of borrowing and the holding of reserves would be examined as a puzzle in traditional preventative saving models (Kawai and Lamberte, 2010).

The interest of empirical studies on sudden stop-events is mainly addressed to macroeconomic variables. Calvo and Talvi (2005), Guidotti et al. (2004), Chari et al. (2005), and Meza and Quintin (2007) are mainly interested in the fall in the global output caused by the SS. Similarly, these studies are interested in monitoring the role of international reserves in stabilizing the economy. Foreign exchange reserves in the literature, are mostly accumulated, to avoid the negative effects of capital inflows (Alfaro and Kanczuk, 2009; Bianchi et al., 2012; Caballero and Panageas, 2005; Jeanne and Rancière, 2011). When the occurrence of crises is less compared to the vulnerability of recent years, huge volumes of international reserves are collected and saved. The inability to rationalize the level of reserves accumulated by emerging countries has led Obstfeld, Shambaugh, and Taylor, (2010) to declare the predictive failure of existing SS theories.

\subsection{Anticipating sudden stops}

Studies on sudden stops mainly focus on the use of event analytic approaches. These methods try to determine the periods of SS through careful selections on the data of the current account and trade balance. The empirical literature has studied rigorously the factors intervening to determine the probability that a SS appears. Among the studies, Guidotti et al. (2004) defined empirically the appearance of a SS event when global capital flow falls by more than one standard deviation from their average over the analysis period.

A SS is defined as a large fall in capital flows, as measured by a year-over-year increase in the current account/gross domestic product ratio by more than two standard deviations above the average change in this ratio (Calvo et al. 2006; 
Milesi-Ferretti and Razin, 2000). These authors also give a second definition of SS, they consider it to be systemic when the fluctuation of the J.P. Morgan Emerging Markets Bond Index (EMBI) exceeds its mean by twice its standard deviation. A third determinant to isolate the SS is given by Calvo et al. (2005), an enormous and abnormally fall in global output.

Many studies suggest that sudden stops events arise from the properties of some domestic variables (Edwards, 2007; Calvo 2002; Cavallo and Frankel, 2004). Several macroeconomic aggregates are affected by massive inflows of foreign capital. for example, there will be an increase in the current account deficit, a depreciation of the local currency, a total relaxation of bank credit to the private sector or distortions in the balance sheets of banks and domestic firms which have funds borrowed in foreign currency (Alfaro et al., 2014).

The empirical literature on the balance of payment crises is also rich in the drivers of SS periods. The current account deficit constitutes the key variable and which knew the most agreement to test the possible appearance of SS in the countries using a fixed exchange rate regime compared to those using a flexible regime (Levy-Yeyati and Sturzenegger, 2005).

There are also other explanatory variables of SS which were also used in empirical studies. A high ratio of foreign borrowing/net exports is likely to increase the likelihood of SS. Besides, the dollarization of the liabilities measured by the ratio liabilities in the foreign currency of the financial sector / M2. Contrary to the variety of predictors of sudden stops, there was no agreement, among the empirical studies, about the optimal policy both to manage the capital flows to predict these SS and to limit their negative impacts on the economy. Although the deficiency noted in empirical studies, a large theoretical literature has focused on the predictive role of the three policies for managing capital flows: exchange reserves, foreign borrowing, and capital control. Korinek and Mendoza (2014) demonstrate that an internal decision for holding reserves diminishes the probability of sudden stops. During major macroeconomic imbalances, policymakers cannot be solvent for their loans without proceeding with liquidations. This process causes sudden stops especially if lenders refuse to give more relaxation in repayment of these loans. Reserves can, in this case, help to reduce the probability of sudden stops by offering repayment guarantees to lenders.

The vision about the advantages of capital account openness, established in 1973, has been modified over the last few years/the last five decades???resulting in finding out all the weak spots /he shortcomings of this practice. Even international financial organizations recommend a comeback to restrictive policies on capital movements (Alfaro et al., 2004). These recommendations have been followed, in several emerging countries, by the introduction of constraints, especially on the short-term capital inflows, which are seen as an essential source of financial 
instability. Likewise, Taxes on foreign currency loans, which are a source of sudden stop events, are broadly part of capital control policies (Korinek, 2011).

Does financial liberalization rise the probability of the occurence of SS? To what extent do capital controls reduce the likelihood of the occurrence of SS event? The role of capital control in predicting SS is still unclear. Evidence shows that these controls reduce capital flow reversal and thus reduce the probability of sudden stops. The facts show that restrictive policy on capital movements reduces the reversible shifts of capital flows and therefore the probability of an SS. Unfortunately, empirical studies have not been able to validate this theoretical proof. The majority of empirical results founded show that even with capital controls the probability of a SS event is not reduced (Edwards, 2004).

Despite that several studies have used international reserves and foreign borrowing as two instruments of macroeconomic policy, their precautionary function for the SS has been less reported and, generally, includes only one variable in the empirical regressions. Here we use quite a number of variables reflecting both reserves and borrowing. For capital control, the analysis uses recent indexes of restrictions on capital movements, four indexes established by the studies of Chinn and Ito, (2006), and Fernandez et al. (2016).

\subsection{Sudden stops and macroeconomic aggregates}

The junction between the economic sphere and financial sphere is the central focus of the debate on sudden stops, and more precisely, on the link between financial vulnerability and macroeconomic imbalances. Calvo and Talvi (2005) are interested in the case of Latin America and the severe macroeconomic conditions following periods of sudden stops which drastically reduced the growth rate of these countries. The case of Chile attracted particular interest from these authors. Despite a highly robust macroeconomic situation and heavy restrictive policies applied to capital inflows, the country was not spared from a crisis in capital flows and devastating macroeconomic consequences in the wake of the Russian crisis. Following loans previously contracted from outside, the SS can reduce an adverse shock to global income, like a decline in the terms of trade. A similar shock can be accompanied by degradation in the current account and a rise in the inflows.

The occurrence of sudden stops and lowering the external debt had its consequence in a high current account adaptation and exchange rate depreciation. In contrast, the debt alleviation and the adjustment of the current account can greatly reduce the level of investment. This reduction in investment has made it possible to meet the stricter conditions of external financing. A drop in the investment of around $20 \%$ was seen just after the Russian crisis. Calvo, Izquierdo, and Talvi (2006) find that no credit restoration from either abroad or inside and a very limited investment restoration are detected during the reversal situation of capital flows. 
Some studies use a standard equilibrium model to demonstrate that high constraints on external debt can generate a SS (Chari, Kehoe and McGrattan, 2005). The authors find that these SS are not the main cause of the decline in production, on the contrary, they help to increase the output. Consequently, such models need to integer other factors, which have unfavorable impacts on production. These factors are so influential to submerge the favorable impact of the SS.

Other studies have investigated the effects on the global well-being of a country and not paying attention to a separate macroeconomic aggregate. These effects can come from income inequality and other social indicators. Among these studies, Bilan et al. (2020) were more interested in the effects of income distribution on overall social well-being, find that fair income distribution and low-income inequality lead to economic progress and social well-being. Fazaalloh, A. M. (2019) also studied the impacts of foreign direct investment on the overall welfare. The author uses the income inequality for the case of Indonesia as a proxy to the overall social well-being and finds that a trade-off between economic growth and income inequality, particularly in developing countries, frequently occurs. FDI has indirect and negative effects on income inequality, via economic growth. Consequently, SS of foreign direct investment can affect the global well-being of the state. Considered as part of flows generating SS, FDI is also focused by Vasa and Angeloska (2020). The authors have analyzed the correlation between FDI and economic growth. Vasa and Angeloska (2020) emphasis on the variables that are considerably influencing changes and impact on FDI in Serbia. The authors suggest a very weak correlation between FDI inflows and increased GDP growth. The GDP growth has strong correlations with industry growth, FDI inflow, and FDI outflow. Other studies have concentrated on the factors inherent to the firms which create these sudden investment outflows. Among these studies, Abidi et al. (2018) have studied the importance of FDI in the MENA region. Their study examines the extent to which Gulf Cooperation Council firms' decisions to conduct investments in MENA region are explained by their characteristics (size, age, performance, state ownership, and debt structure). The findings reveal that while the firm's size and performance exert a positive effect on a firm's decision to expand within MENA region, state ownership has a negative influence.

Given that the idea of SS generates a grievous macroeconomic unbalances is not accordant, our study analyzes its effects on the main macroeconomic fundamentals (gross domestic product, investment, consumption, and unemployment). According to Calvo and Reinhart (1999) that generally, the SS does not happen in developed countries, leads to the conclusion that SS is a central feature of emergent crises spreading over the other countries around the world. This is why the SS effect analysis is applied to the total sample of 200 countries, including developed and emerging economies. These impacts may be expected to be clearer among developing countries than among the developed ones. 


\section{Methodology}

\subsection{Identifying SS events}

A country that receives a large volume of foreign capital is suddenly and unexpectedly deprived of these inflows, such is the general context of a sudden stop. In particular, this event occurs when there is a drop of at least $5 \%$ in gross domestic product per year (Edwards 2004). According to Guidotti et al. (2004), Agosin and Huaita (2012) and Agosin, Díaz, Karnani (2019), this event occurs if the annual decline in the financial account is at least equal to one standard deviation from its average and also greater than $5 \%$ of gross domestic product. Specifically, a SS occurs when $S S_{i t}=1$ and defined as:

$S S_{i t}=\left\{\begin{array}{l}1 \text { if } \Delta F A_{i, t}<\overline{\Delta F A_{\iota}}-\sigma_{\Delta F_{i}} \text { and }\left|\frac{\Delta F A_{i, t}}{G D P_{i, t}}\right| \geq 5 \% \text {, whenever } F A_{i, t-1}>0 \text { and } F A_{i, t}=0 \\ 0 \quad \text { otherwise }\end{array}\right.$

where $\Delta F A_{i, t}=F A_{i, t}-F A_{i, t-1}$ is the annual variation in the financial account.

\subsection{Predict sudden stops}

The paper has contributed to the past analysis on the probability of SS by the employ of a set of explicative variables:

- Broad money of GDP,

- Current account balance,

- Liabilities dollarization (net incurrence of liabilities),

- Exports of goods and services,

- Terms of trade,

- Real effective exchange rate,

- Real interest rate.

The three policies for managing capital flows are defined by the following dimensions:

- For international reserves, we use four variables: reserves and related items, total reserves, net foreign assets, and bank liquid reserves to bank assets ratio.

- For external debt, we use two variables: debt service on external debt, total and external debt stocks.

- Capital controls indexes are defined in Table 1 and consist of four indexes: ka, Kai, Kao, and KAOPEN. 
Table 1: Capital control indexes

\begin{tabular}{|l|l|l|}
\hline \multicolumn{1}{|c|}{ Index } & \multicolumn{1}{|c|}{ Definition } & \multicolumn{1}{c|}{ Source } \\
\hline ka & $\begin{array}{l}\text { Overall restrictions index (all } \\
\text { asset categories) }\end{array}$ & $\begin{array}{l}\text { Fernández, Klein, Rebucci, Schindler, and } \\
\text { Uribe (2016) "Capital Control Measures: A } \\
\text { New Dataset" }\end{array}$ \\
\hline kai & $\begin{array}{l}\text { Overall inflow restrictions index } \\
\text { (all asset categories) }\end{array}$ & $\begin{array}{l}\text { Overall outflow restrictions } \\
\text { index (all asset categories) }\end{array}$ \\
\hline kao & $\begin{array}{l}\text { The extent of openness in } \\
\text { capital account transactions }\end{array}$ & $\begin{array}{l}\text { Chinn, M. D., and H. Ito, The Chinn-Ito } \\
\text { Index, http://web.pdx.edu/ ito/Chinn-Ito_ } \\
\text { website.htm, last updated July 2017. }\end{array}$ \\
\hline
\end{tabular}

Source: Fernández, Klein, Rebucci, Schindler, and Uribe (2016) "Capital Control Measures: A New Dataset"; Chinn, M. D., and H. Ito, The Chinn-Ito Index, http://web.pdx. edu/ ito/Chinn-Ito_website.htm, last updated July 2017.

According to Gourinchas and Jeanne (2012) and Hur, Kondo (2016) a panel logit model with country fixed effects was applied to regress the following equation:

$$
\operatorname{Pr}\left(S S_{t}^{i}=1 \mid X_{i}\right)=\frac{\exp \left(\alpha_{i}+\beta X_{i}\right)}{1+\exp \left(x_{i}+\beta X_{i}\right)}
$$

where $S S_{t}^{i}$ define if an economy country ' $\mathrm{i}$ ' is in a sudden stop period in the next ' $\mathrm{t}$ ' years, and $\mathrm{X}_{\mathrm{i}}$ denotes, classical determinants previously defined in this section. As a hypothesis for the study, SS probability becomes low with:

- High foreign exchange reserves,

- Low foreign borrowing,

- Rigid capital controls.

We empirically follow the evolution of some macroeconomic fundamentals before and after the periods of sudden stops. As assumed in this study, there will be deterioration in the macroeconomic situation after the SS. The study except that this degradation will be more remarkable in developing economies than in developed (Benigno and Fornaro, 2012).

\section{Empirical data and analysis}

\subsection{Data}

The study is applied for a sample of 200 developed and developing countries, over the period 1995-2019. These are annual data collected from various sources, mainly statistics from the International Monetary Fund (IFS) and the World Bank database (WDI). 
For capital control, we use the Chinn-Ito financial openness index (KAOPEN) to designate the extent of restrictions applied by a country (Chinn and Ito, 2006). And also we use three indexes defined by Fernandez et al. (2016).

\subsection{Sudden stops periods}

Total capital flows are determined using various types of liabilities on FDI, PI, and all other investments. It was majorly calculated by the sum of net portfolio investment, net foreign direct investment, and net flows on external debts. The study follows the definition of Guidotti et al. (2004), Agosin and Huaita (2012) and Agosin, Díaz, Karnani (2019) for SS periods. Events of brusque reversals are determined when capital inflows decline exceed the standard deviation of their mean fluctuation within the analysis period, additionally, when that drop is at a minimum of $5 \%$ of GDP. If the two previous conditions are satisfied we judge that the period is "intense", if not, "normal".

Table 2 displays annual periods of "normal" and "intense" sudden stops for developing and developed economies. The results show that the mean for developing economies is generally shorter in comparison to developed economies.

Table 2: SS Periods for developing and developed economies

\begin{tabular}{|c|c|c|c|c|}
\hline \multirow{2}{*}{ Years } & \multicolumn{2}{|c|}{ Normal } & \multicolumn{2}{c|}{ Intense } \\
\cline { 2 - 5 } & $\begin{array}{c}\text { Developing } \\
\text { Economies }\end{array}$ & $\begin{array}{c}\text { Developed } \\
\text { Economies }\end{array}$ & $\begin{array}{c}\text { Developing } \\
\text { Economies }\end{array}$ & $\begin{array}{c}\text { Developed } \\
\text { Economies }\end{array}$ \\
\hline 1985 & 2.84 & 8.46 & 4.72 & 5.56 \\
\hline 1986 & 2.75 & 6.77 & 4.14 & 5.26 \\
\hline 1987 & 4.75 & 6.48 & 7.53 & 2.79 \\
\hline 1988 & 3.49 & 7.53 & 5.65 & 5.63 \\
\hline 1989 & 6.11 & 4.94 & 5.04 & 8.06 \\
\hline 1990 & 6.71 & 5.31 & 5.34 & 8.22 \\
\hline 1991 & 2.93 & 4.91 & 6.01 & 7.42 \\
\hline 1992 & 2.91 & 4.12 & 5.23 & 5.16 \\
\hline 1993 & 3.34 & 2.87 & 6.00 & 3.69 \\
\hline 1994 & 1.93 & 2.12 & 7.92 & 4.25 \\
\hline 1995 & 6.38 & 2.60 & 8.57 & 6.35 \\
\hline 1996 & 818 & 1.14 & 8.65 & 6.48 \\
\hline 1997 & 5.21 & 5.11 & 7.54 & 7.07 \\
\hline 1998 & 9.70 & 3.47 & 6.56 & 4.91 \\
\hline 1999 & 7.65 & 3.68 & 5.76 & 5.10 \\
\hline 2000 & 8.83 & 6.80 & 5.48 & 5.14 \\
\hline 2001 & 9.60 & 2.42 & 4.92 & 5.07 \\
\hline 2002 & 6.45 & 2.29 & 4.87 & 5.25 \\
\hline 2003 & 7.06 & 2.71 & 5.75 & 5.75 \\
\hline 2004 & 5.33 & 5.39 & 2.20 & 5.18 \\
\hline & & & & \\
\hline
\end{tabular}




\begin{tabular}{|c|c|c|c|c|}
\hline \multirow{2}{*}{ Years } & \multicolumn{2}{|c|}{ Normal } & \multicolumn{2}{c|}{ Intense } \\
\cline { 2 - 5 } & $\begin{array}{c}\text { Developing } \\
\text { Economies }\end{array}$ & $\begin{array}{c}\text { Developed } \\
\text { Economies }\end{array}$ & $\begin{array}{c}\text { Developing } \\
\text { Economies }\end{array}$ & $\begin{array}{c}\text { Developed } \\
\text { Economies }\end{array}$ \\
\hline 2005 & 5.08 & 4.87 & 2.53 & 5.59 \\
\hline 2006 & 6.48 & 3.04 & 4.58 & 5.79 \\
\hline 2007 & 7.43 & 3.17 & 3.05 & 5.51 \\
\hline 2008 & 4.41 & 4.44 & 2.31 & 4.91 \\
\hline 2009 & 5.99 & 2.19 & 3.79 & 5.10 \\
\hline 2010 & 5.39 & 3.14 & 2.24 & 3.06 \\
\hline 2011 & 5.64 & 2.88 & 3.83 & 3.57 \\
\hline 2012 & 6.82 & 1.99 & 2.14 & 3.39 \\
\hline 2013 & 5.56 & 6.74 & 3.71 & 12.51 \\
\hline 2014 & 3.84 & 6.56 & 3.68 & 4.29 \\
\hline 2015 & 4.28 & 8.37 & 2.20 & 3.56 \\
\hline 2016 & 3.94 & 7.27 & 3.91 & 3.93 \\
\hline 2017 & 4.68 & 3.54 & 2.68 & 4.43 \\
\hline 2018 & 3.18 & 2.78 & 2.28 & 3.89 \\
\hline 2019 & 3.85 & 4.54 & 1.55 & 5.56 \\
\hline Mean & 4.39 & 5.15 & 4.83 & 5.21 \\
\hline
\end{tabular}

Source: author's calculations

\subsection{Forecast sudden stops}

To detect a sudden stop event with countries' fixed effects, we used a discrete choice panel model. This type of model is often used in the early warning literature of financial crisis prevention. We have chosen the logit models instead of the probit models based on the results of Hausman's specification test. This test confirms the rejection of the hypothesis that the profit estimator is consistent and efficient.

Similarly, the choice of fixed effects instead of random effects is motivated by the fact that traditional probit models with a random effect require independence of unobservable country effects on the independent variables. Whereas with a fixed effect logit panel model, we can have robust coefficient estimates without the unobservable country effects be associated with the independent variables.

Regressions are executed with the totality of 200 countries included in the panel. Respectively the results of the regressions for the explanatory variables of sudden stops concerning the three dimensions of our study, foreign exchange reserves, foreign borrowing, and capital control are presented in Tables 3-5.

The results demonstrated a statistical significance of major factors affecting the probability of sudden stops and have the expected sign. The probability of sudden stops is greater when there is a slowdown in economic growth and there is more risk aversion among the agents operating on the financial markets. Contrarily, the overall liquidity rates and the long-term interest rate are insignificant. 
Concerning the combination of policies for managing capital flow, the results show a significant relationship between foreign borrowing and foreign exchange reserves. A high ratio of reserves to debts is associated with a low probability of sudden stops. Countries with a considerable stock of foreign exchange reserves relative to their external debt are less vulnerable to a sudden stop.

Table 3: Fixed effects model for foreign exchange reserves

\begin{tabular}{|c|c|c|c|c|}
\hline \multirow[b]{2}{*}{$\begin{array}{l}\text { Independent } \\
\text { variables }\end{array}$} & \multicolumn{4}{|c|}{ Foreign Exchange Reserves } \\
\hline & $\begin{array}{l}\text { Bank Liquid } \\
\text { Reserves }\end{array}$ & $\begin{array}{c}\text { Total } \\
\text { Reserves }\end{array}$ & $\begin{array}{l}\text { Net Foreign } \\
\text { Assets }\end{array}$ & $\begin{array}{l}\text { Reserves and } \\
\text { Related Items }\end{array}$ \\
\hline Broad money of GDP & $\begin{array}{r}-0.130^{* * *} \\
(0.020)\end{array}$ & $\begin{array}{r}0.516 \\
(0.326)\end{array}$ & $\begin{array}{r}0.120^{* * *} \\
(0.016)\end{array}$ & $\begin{array}{r}-0.022 \\
(0.232)\end{array}$ \\
\hline Current account balance & $\begin{array}{r}0.459^{* * *} \\
(0.031) \\
\end{array}$ & $\begin{array}{r}1.920^{* * *} \\
(0.047) \\
\end{array}$ & $\begin{array}{r}0.003^{* * *} \\
(0.000) \\
\end{array}$ & $\begin{array}{r}0.471^{* * *} \\
(0.017) \\
\end{array}$ \\
\hline $\begin{array}{l}\text { Exports of goods and } \\
\text { services }\end{array}$ & $\begin{array}{l}0.010^{* *} \\
(0.075) \\
\end{array}$ & $\begin{array}{r}0.247^{* *} \\
(0.094) \\
\end{array}$ & $\begin{array}{r}0.279^{* *} \\
(0.080) \\
\end{array}$ & $\begin{array}{r}0.032^{* * * *} \\
(0.003) \\
\end{array}$ \\
\hline $\begin{array}{l}\text { Final consumption } \\
\text { expenditure }\end{array}$ & $\begin{array}{r}-0.182^{* *} \\
(0.068) \\
\end{array}$ & $\begin{array}{r}0.036 \\
(0.375) \\
\end{array}$ & $\begin{array}{r}-0.002^{* *} \\
(0.035) \\
\end{array}$ & $\begin{array}{r}-0.191^{* *} \\
(0.051) \\
\end{array}$ \\
\hline GDP & $\begin{array}{r}0.306^{* * *} \\
(0.026)\end{array}$ & $\begin{array}{r}0.518 \\
(0.378)\end{array}$ & $\begin{array}{r}-0.016^{* * *} \\
(0.007)\end{array}$ & $\begin{array}{r}0.014 \\
(0.950)\end{array}$ \\
\hline GDP Growth Annual & $\begin{array}{r}-0.065 \\
(0.001) \\
\end{array}$ & $\begin{array}{r}0.192 \\
(0.224) \\
\end{array}$ & $\begin{array}{r}-0.613 * * \\
(0.076) \\
\end{array}$ & $\begin{array}{r}0.994^{* *} \\
(0.085) \\
\end{array}$ \\
\hline GDP per capita & $\begin{array}{r}0.001^{* * * *} \\
(0.000) \\
\end{array}$ & $\begin{array}{l}0.058^{* *} \\
(0.081)\end{array}$ & $\begin{array}{r}0.003^{* * *} \\
(0.000) \\
\end{array}$ & $\begin{array}{r}-0.427 \\
(0.249) \\
\end{array}$ \\
\hline $\begin{array}{l}\text { Net acquisition of } \\
\text { finance }\end{array}$ & $\begin{array}{r}0.360 \\
(0.276) \\
\end{array}$ & $\begin{array}{r}-0.001^{* * *} \\
(0.000) \\
\end{array}$ & $\begin{array}{r}-0.002^{* *} \\
(0.048) \\
\end{array}$ & $\begin{array}{r}-0.151 \\
(0.740) \\
\end{array}$ \\
\hline $\begin{array}{l}\text { Net financial account } \\
\text { behavior }\end{array}$ & $\begin{array}{c}0.368^{* *} \\
(0.076) \\
\end{array}$ & $\begin{array}{c}0.081^{* *} \\
(0.088) \\
\end{array}$ & $\begin{array}{r}0.473 \\
(0.180) \\
\end{array}$ & $\begin{array}{r}0.054^{* * *} \\
(0.008) \\
\end{array}$ \\
\hline $\begin{array}{l}\text { Net incurrence of } \\
\text { liabilities }\end{array}$ & $\begin{array}{l}0.508^{* *} \\
(0.096) \\
\end{array}$ & $\begin{array}{r}-0.711 \\
(0.179) \\
\end{array}$ & $\begin{array}{r}0.004 \\
(0.310) \\
\end{array}$ & $\begin{array}{l}0.281^{* *} \\
(0.083) \\
\end{array}$ \\
\hline $\begin{array}{l}\text { Real effective exchange } \\
\text { rate }\end{array}$ & $\begin{array}{r}0.103^{* * *} \\
(0.030) \\
\end{array}$ & $\begin{array}{r}0.254 \\
(0.152) \\
\end{array}$ & $\begin{array}{l}0.004^{* *} \\
(0.098) \\
\end{array}$ & $\begin{array}{l}0.507^{* *} \\
(0.078) \\
\end{array}$ \\
\hline Real interest rate & $\begin{array}{l}0.213^{* *} \\
(0.085) \\
\end{array}$ & $\begin{array}{r}0.154^{* * *} \\
(0.027) \\
\end{array}$ & $\begin{array}{r}0.001 \\
(0.322) \\
\end{array}$ & $\begin{array}{r}0.555^{* * *} \\
(0.031) \\
\end{array}$ \\
\hline $\begin{array}{l}\text { Terms of trade } \\
\text { adjustment }\end{array}$ & $\begin{array}{l}0.286^{* *} \\
(0.081)\end{array}$ & $\begin{array}{r}0.456^{* * *} \\
(0.037) \\
\end{array}$ & $\begin{array}{r}0.131 \\
(0.634) \\
\end{array}$ & $\begin{array}{c}0.161^{* *} \\
(0.076)\end{array}$ \\
\hline Trade of GDP & $\begin{array}{r}0.041^{* * *} \\
(0.012) \\
\end{array}$ & $\begin{array}{r}0.029 \\
(0.116) \\
\end{array}$ & $\begin{array}{r}0.000^{* * *} \\
(0.013) \\
\end{array}$ & $\begin{array}{r}0.018^{* *} \\
(0.089) \\
\end{array}$ \\
\hline Unemployment & $\begin{array}{r}-0.072^{* *} \\
(0.071) \\
\end{array}$ & $\begin{array}{r}0.031^{* * *} \\
(0.049) \\
\end{array}$ & $\begin{array}{r}0.021 \\
(0.130) \\
\end{array}$ & $\begin{array}{r}0.761^{* * * *} \\
(0.087) \\
\end{array}$ \\
\hline
\end{tabular}

*** Significant at the 5\% confidence level; ** Significant at the $10 \%$ confidence level; Standard errors in parenthesis.

Source: author's calculations

Table 3 shows that the current account balance, exports of goods and services, terms of trade, and Trade (\% of GDP) are the most significant variables to explain the different independent variables of foreign exchange reserves. The coefficients 
of these explanatory variables are positive, reflecting their favorable impacts on the accumulation of international reserves. Monetary and foreign exchange policies, across the sample country, also seem to favor the accumulation of foreign exchange reserves. The coefficients of variables real effective exchange rate and real interest rate are positive and significant, defining a favorable influence on the four dependent variables of foreign exchange reserves. The control variables which consider the macroeconomic conditions (GDP growth, employment, and consumption), determine a good framework favoring the attraction of foreign currencies.

Table 4: Fixed effects model for foreign borrowing

\begin{tabular}{|c|c|c|}
\hline \multirow[b]{2}{*}{ Independent variables } & \multicolumn{2}{|c|}{ Foreign Borrowing } \\
\hline & $\begin{array}{c}\text { Debt Service on } \\
\text { Foreign Borrowing }\end{array}$ & $\begin{array}{c}\text { Foreign } \\
\text { Borrowing Stocks }\end{array}$ \\
\hline Broad money of GDP & $\begin{array}{l}0.126^{* *} \\
(0.074)\end{array}$ & $\begin{array}{l}0.002^{* *} \\
(0.052)\end{array}$ \\
\hline Current account balance & $\begin{array}{r}0.153^{* * *} \\
(0.037) \\
\end{array}$ & $\begin{array}{r}0.561^{* * *} \\
(0.014) \\
\end{array}$ \\
\hline Exports of goods and services & $\begin{array}{r}0.086^{* *} \\
(0.056) \\
\end{array}$ & $\begin{array}{r}0.158^{* *} \\
(0.030) \\
\end{array}$ \\
\hline Final consumption expenditure & $\begin{array}{r}0.965 \\
(0.219)\end{array}$ & $\begin{array}{r}0.727^{* * *} \\
(0.015)\end{array}$ \\
\hline GDP current US\% & $\begin{array}{r}0.692 \\
(0.253) \\
\end{array}$ & $\begin{array}{r}-0.138 \\
(0.753) \\
\end{array}$ \\
\hline GDP Growth Annual & $\begin{array}{r}0.018^{* * *} \\
(0.001) \\
\end{array}$ & $\begin{array}{r}-0.215^{* *} \\
(0.067) \\
\end{array}$ \\
\hline GDP per capita & $\begin{array}{l}0.360^{* *} \\
(0.077) \\
\end{array}$ & $\begin{array}{r}0.097^{* *} \\
(0.064) \\
\end{array}$ \\
\hline Net acquisition of finance & $\begin{array}{r}-0.547 \\
(0.144) \\
\end{array}$ & $\begin{array}{r}-0.905 \\
(0.184) \\
\end{array}$ \\
\hline Net financial account behavior & $\begin{array}{r}-0.009^{* *} \\
(0.081) \\
\end{array}$ & $\begin{array}{r}-0.235 \\
(0.496) \\
\end{array}$ \\
\hline Net incurrence of liabilities & $\begin{array}{r}0.054^{* *} \\
(0.085) \\
\end{array}$ & $\begin{array}{r}0.694^{* *} \\
(0.067) \\
\end{array}$ \\
\hline Real effective exchange rate & $\begin{array}{r}-0.022^{* *} \\
(0.075) \\
\end{array}$ & $\begin{array}{r}0.185^{* * * *} \\
(0.020) \\
\end{array}$ \\
\hline Real interest rate & $\begin{array}{r}-0.264^{* *} \\
(0.052) \\
\end{array}$ & $\begin{array}{l}0.037^{* *} \\
(0.076) \\
\end{array}$ \\
\hline Terms of trade adjustment & $\begin{array}{l}0.284^{* *} \\
(0.095)\end{array}$ & $\begin{array}{r}0.032 \\
(0.280) \\
\end{array}$ \\
\hline Trade of GDP & $\begin{array}{r}-0.002^{* * *} \\
(0.023) \\
\end{array}$ & $\begin{array}{r}-0.748^{* *} \\
(0.074) \\
\end{array}$ \\
\hline Unemployment & $\begin{array}{r}-0.014^{* *} \\
(0.096)\end{array}$ & $\begin{array}{r}-0.045^{* *} \\
(0.035)\end{array}$ \\
\hline
\end{tabular}

*** Significant at the 5\% confidence level; ** Significant at the $10 \%$ confidence level; Standard errors in parenthesis.

Source: author's calculations 
Table 4 displays results for two dependent variables proxies of foreign borrowing: debt services on foreign borrowing, and foreign borrowing stocks. The findings show that international trade variables such as trade, terms of trade, current account balance, and exports have positive effects on both the accumulation of external debt and the cost of this debt. Monetary and exchange rate policies also seem to support the accumulation of external debts but, on the contrary, reduce the burden of these debts. The coefficients of the real effective exchange rate and real interest rate are negative and significant to explain Debt service on foreign borrowing and are positive and significant to explain foreign borrowing stocks. Macroeconomic conditions, through GDP, consumption, and employment, support the recourse to foreign borrowing and therefore the debt burden.

Table 5: Fixed effects model for capital controls

\begin{tabular}{|c|c|c|c|c|}
\hline \multirow{2}{*}{ Independent variables } & \multicolumn{4}{|c|}{ Capital Controls } \\
\hline & $\mathrm{Ka}$ & Kai & Kao & KAOPEN \\
\hline Broad money of GDP & $\begin{array}{r}-0.070 * * * \\
(0.011)\end{array}$ & $\begin{array}{r}-0.513^{* * *} \\
(0.026)\end{array}$ & $\begin{array}{r}-0.555^{* *} \\
(0.081)\end{array}$ & $\begin{array}{r}0.560^{* *} \\
(0.076)\end{array}$ \\
\hline Current account balance & $\begin{array}{r}-0.555^{* * *} \\
(0.028)\end{array}$ & $\begin{array}{r}-0.318^{* *} \\
(0.067)\end{array}$ & $\begin{array}{r}-0.191^{* *} \\
(0.031)\end{array}$ & $\begin{array}{r}0.163^{* * *} \\
(0.028)\end{array}$ \\
\hline $\begin{array}{l}\text { Exports of goods and } \\
\text { services }\end{array}$ & $\begin{array}{r}-0.093^{* *} \\
(0.066)\end{array}$ & $\begin{array}{r}-0.052^{* *} \\
(0.063)\end{array}$ & $\begin{array}{r}-0.045^{* *} \\
(0.061)\end{array}$ & $\begin{array}{r}0.025 \\
(0.102)\end{array}$ \\
\hline $\begin{array}{l}\text { Final consumption } \\
\text { expenditure }\end{array}$ & $\begin{array}{r}0.341^{* *} \\
(0.065) \\
\end{array}$ & $\begin{array}{l}0.031^{* *} \\
(0.079) \\
\end{array}$ & $\begin{array}{r}0.011^{* * *} \\
(0.031) \\
\end{array}$ & $\begin{array}{r}-0.820 \\
(0.331) \\
\end{array}$ \\
\hline GDP current US\% & $\begin{array}{r}-0.414 \\
(0.626)\end{array}$ & $\begin{array}{r}0.435^{* * *} \\
(0.046) \\
\end{array}$ & $\begin{array}{r}0.141^{* * *} \\
(0.031) \\
\end{array}$ & $\begin{array}{r}-0.444 \\
(0.366)\end{array}$ \\
\hline GDP Growth Annual & $\begin{array}{r}-0.156 \\
(0.149) \\
\end{array}$ & $\begin{array}{r}-0.196^{* *} \\
(0.089) \\
\end{array}$ & $\begin{array}{r}-0.124^{* * *} \\
(0.049) \\
\end{array}$ & $\begin{array}{r}-0.012^{* * *} \\
(0.000) \\
\end{array}$ \\
\hline GDP per capita & $\begin{array}{r}-4.37 * * * \\
(0.423) \\
\end{array}$ & $\begin{array}{r}-1.165^{* * *} \\
(0.010) \\
\end{array}$ & $\begin{array}{r}-0.541^{* * * *} \\
(0.069) \\
\end{array}$ & $\begin{array}{r}-0.972^{* *} \\
(0.075) \\
\end{array}$ \\
\hline $\begin{array}{l}\text { Net acquisition of } \\
\text { finance }\end{array}$ & $\begin{array}{r}-0.230^{* *} \\
(1.073) \\
\end{array}$ & $\begin{array}{r}-0.001^{* * *} \\
(0.000) \\
\end{array}$ & $\begin{array}{r}-0.370^{* *} \\
(0.083) \\
\end{array}$ & $\begin{array}{r}0.538^{* * *} \\
(0.245) \\
\end{array}$ \\
\hline $\begin{array}{l}\text { Net financial account } \\
\text { behavior }\end{array}$ & $\begin{array}{r}-0.391^{* *} \\
(0.071) \\
\end{array}$ & $\begin{array}{r}-0.297^{* * *} \\
(0.009) \\
\end{array}$ & $\begin{array}{r}-0.223^{* *} \\
(0.084) \\
\end{array}$ & $\begin{array}{r}0.936 \\
(0.724) \\
\end{array}$ \\
\hline $\begin{array}{l}\text { Net incurrence of } \\
\text { liabilities }\end{array}$ & $\begin{array}{r}0.871^{* * *} \\
(0.041) \\
\end{array}$ & $\begin{array}{r}0.137^{* * *} \\
(0.037) \\
\end{array}$ & $\begin{array}{r}0.369 \\
(0.219) \\
\end{array}$ & $\begin{aligned} 0.013^{* *} \\
(0.082)\end{aligned}$ \\
\hline $\begin{array}{l}\text { Real effective exchange } \\
\text { rate }\end{array}$ & $\begin{array}{r}0.181^{* * *} \\
(0.023)\end{array}$ & $\begin{array}{r}0.259^{* * *} \\
(0.042)\end{array}$ & $\begin{array}{r}439.9^{* *} \\
(0.081)\end{array}$ & $\begin{array}{r}-0.065^{* *} \\
(0.087)\end{array}$ \\
\hline Real interest rate & $\begin{array}{r}0.001^{* * *} \\
(0.021) \\
\end{array}$ & $\begin{array}{l}0.162 * * \\
(0.085) \\
\end{array}$ & $\begin{array}{r}4.870 \\
(1.751) \\
\end{array}$ & $\begin{array}{r}-0.268^{* * *} \\
(0.003) \\
\end{array}$ \\
\hline $\begin{array}{l}\text { Terms of trade } \\
\text { adjustment }\end{array}$ & $\begin{array}{r}-0.056^{* *} \\
(0.070) \\
\end{array}$ & $\begin{array}{r}-0.454^{* *} \\
(0.077) \\
\end{array}$ & $\begin{array}{r}-0.056^{* * *} \\
(0.040) \\
\end{array}$ & $\begin{array}{r}0.016^{* *} \\
(0.078) \\
\end{array}$ \\
\hline Trade of GDP & $\begin{array}{r}-0.871^{* *} \\
(0.071) \\
\end{array}$ & $\begin{array}{r}-0.780^{* *} \\
(0.058) \\
\end{array}$ & $\begin{array}{r}-3.871 \\
(1.601) \\
\end{array}$ & $\begin{array}{r}-0.705 \\
(0.330) \\
\end{array}$ \\
\hline Unemployment & $\begin{array}{r}0.014^{* * *} \\
(0.010) \\
\end{array}$ & $\begin{array}{r}0.324^{* * *} \\
(0.014) \\
\end{array}$ & $\begin{array}{r}-0.411 \\
(8.311) \\
\end{array}$ & $\begin{array}{r}0.069 \\
(0.040) \\
\end{array}$ \\
\hline
\end{tabular}

$* * *$ Significant at the $5 \%$ confidence level; ** Significant at the $10 \%$ confidence level; Standard errors in parenthesis.

Source: author's calculations 
The findings of Table 5 highlight the importance of capital controls to stabilize the economy. The main variables sources of foreign reserves holdings display negative coefficients for Fernández et al. (2016) indexes (ka, kai, and kao) and a positive coefficient for Chinn and Ito (2006) index (kaopen). We must be careful when interpreting these results because these indexes reflect an opposite appearance. High values of ka, kai, and kao mean tighter controls, while for kaopen, the high value reflects fewer controls. For all these indexes, it seems that the variables generating foreign exchange reserves are hampered by capital controls, evidence that has been established in the literature review. Among these variables were particularly cited, current account balance, net acquisition of finance, net financial account, and net incurrence of liabilities. Broad money of GDP (M2 / GDP) is often used in the literature of financial crises as an indicator of financial system instability. This variable shows a positive association with kaopen, and negative with ka, kai, and, kao, indicating that increased capital account liberalization may cause more financial deepening but also generate financial instability. Monetary and exchange rate policies are consistent with restrictive capital flow policies. The coefficients of the real effective exchange rate and real interest rate are positive with ka, kai, and kaopen and negative with kaopen, suggesting accordance with the restrictions applied through capital controls.

\subsection{Impacts of SS on economic fundamentals}

The impact analysis conducted on the consequences of these events of SS on the gross domestic product, consumption, investment, and unemployment, shows disastrous effects. Before periods of sudden stops (Tables 6 and 7), economies with a satisfactory stock of international reserves, low external debt, and tight restriction policy on capital movement are the lowest touched by the spillover risk. We also observe that developing economies are more influenced than developed economies. 
Table 6: Panel logit regressions (prior sudden stop)

\begin{tabular}{|c|c|c|c|c|}
\hline & GDP & Consumption & Investment & Unemployment \\
\hline \multicolumn{5}{|c|}{ Foreign Exchange Reserves } \\
\hline Reserves and related items & $\begin{array}{l}0.294^{* *} \\
(0.076)\end{array}$ & $\begin{array}{l}0.014^{* *} \\
(0.094)\end{array}$ & $\begin{array}{r}0.019 * * * \\
(0.257)\end{array}$ & $\begin{array}{l}-4.415 \\
(0.955)\end{array}$ \\
\hline $\begin{array}{l}\text { Total reserves } \\
(\% \text { of total external debt })\end{array}$ & $\begin{array}{r}3.469 * * * \\
(0.007) \\
\end{array}$ & $\begin{array}{r}0.061^{* *} \\
(0.068) \\
\end{array}$ & $\begin{array}{r}0.027 \\
(0.177) \\
\end{array}$ & $\begin{array}{l}-0.093 \\
(0.184) \\
\end{array}$ \\
\hline $\begin{array}{l}\text { Net foreign assets } \\
\text { (current LCU) }\end{array}$ & $\begin{array}{r}0.015^{* *} \\
(0.74) \\
\end{array}$ & $\begin{array}{r}-0.282^{* *} \\
(0.097) \\
\end{array}$ & $\begin{array}{r}-0.019 * * * \\
(0.000)\end{array}$ & $\begin{array}{r}-0.643 \\
(2.071)\end{array}$ \\
\hline \multicolumn{5}{|c|}{ Foreign Borrowing } \\
\hline $\begin{array}{l}\text { Debt service on external debt, } \\
\text { total (TDS, current US\$) }\end{array}$ & $\begin{array}{r}0.060 * * * \\
(0.008)\end{array}$ & $\begin{array}{l}-4130 \\
(0.368)\end{array}$ & $\begin{array}{r}0.014 * * \\
(0.056)\end{array}$ & $\begin{array}{r}-0.049 \\
(0.121)\end{array}$ \\
\hline $\begin{array}{l}\text { External debt stocks, total } \\
\text { (DOD, current US\$) }\end{array}$ & $\begin{array}{l}-0.050 \\
(0.269)\end{array}$ & $\begin{array}{r}0.077 \\
(0.197) \\
\end{array}$ & $\begin{array}{l}-1.591 \\
(0.266)\end{array}$ & $\begin{array}{l}-0.001 \\
(0.271)\end{array}$ \\
\hline \multicolumn{5}{|c|}{ Capital Controls } \\
\hline $\mathrm{Ka}$ & $\begin{array}{l}-0.729 \\
(0.529) \\
\end{array}$ & $\begin{array}{c}0.057^{* *} \\
(0.078) \\
\end{array}$ & $\begin{array}{l}-0.280 \\
(0.718) \\
\end{array}$ & $\begin{array}{r}-1.393^{* * *} \\
(0.055) \\
\end{array}$ \\
\hline Kai & $\begin{array}{r}0.327 \\
(0.464)\end{array}$ & $\begin{array}{r}-0.240^{* *} \\
(0.067) \\
\end{array}$ & $\begin{array}{l}-0.000 \\
(0.091)\end{array}$ & $\begin{array}{l}-0.081 \\
(0.748)\end{array}$ \\
\hline Kao & $\begin{array}{r}-0.142^{* * *} \\
(0.037) \\
\end{array}$ & $\begin{array}{l}-0.827 \\
(0.107)\end{array}$ & $\begin{array}{r}-0.016^{* * *} \\
(0.008) \\
\end{array}$ & $\begin{array}{r}-1.466^{* * *} \\
(0.042) \\
\end{array}$ \\
\hline KAOPEN & $\begin{array}{l}-0.093 \\
(0.228)\end{array}$ & $\begin{array}{r}0.052^{* * *} \\
(0.018)\end{array}$ & $\begin{array}{l}-0.048 \\
(0.744)\end{array}$ & $\begin{array}{l}0.016^{* *} \\
(0.079)\end{array}$ \\
\hline
\end{tabular}

*** Significant at the 5\% confidence level; ** Significant at the $10 \%$ confidence level; Standard errors in parenthesis.

Source: author's calculations

The results in Table 6 show that, before sudden stops, there are positive impacts of foreign exchange reserves variables on the macroeconomic aggregates. This is the result of periods of massive capital inflows, among other things, in the form of exchange reserves. There has been empirical literature evidence that these inflows have to lead to high economic growth rates, particularly, for emerging countries. Debts have often been seen as a means of promoting the economic activity of a country if they are well allocated and are particularly investment-oriented. This is observed through positive and significant coefficients for GDP and Investment. Unfortunately, for other variables, consumption, and employment, there are no external debt impacts, the coefficients are non-significant. Considering capital control indexes, the effects are diverse on GDP, consumption, investment, and employment, which do not allow giving a clear interpretation. We admit that these capital controls were weak for the periods before SS, their impact was thus reduced. 
Table 7: Panel logit regressions (after a sudden stop)

\begin{tabular}{|c|c|c|c|c|}
\hline & GDP & Consumption & Investment & Unemployment \\
\hline \multicolumn{5}{|c|}{ Foreign Exchange Reserves } \\
\hline Reserves and related items & $\begin{array}{r}-0.242^{* *} \\
(0.067)\end{array}$ & $\begin{array}{r}-0.184^{* *} \\
(0.095)\end{array}$ & $\begin{array}{r}-0.237^{* * *} \\
(0.027)\end{array}$ & $\begin{array}{r}0.251^{* * *} \\
(0.048)\end{array}$ \\
\hline $\begin{array}{l}\text { Total reserves ( } \% \text { of total } \\
\text { external debt) }\end{array}$ & $\begin{array}{r}-0.198^{* *} \\
(0.068)\end{array}$ & $\begin{array}{r}-0.076^{* *} \\
(0.090)\end{array}$ & $\begin{array}{l}-0.868 \\
(0.932)\end{array}$ & $\begin{array}{l}0.681^{* *} \\
(0.087)\end{array}$ \\
\hline Net foreign assets & $\begin{array}{r}-0.453^{* *} \\
(0.099)\end{array}$ & $\begin{array}{r}-0.071^{* *} \\
(0.075)\end{array}$ & $\begin{array}{r}-0.021^{* * *} \\
(0.033)\end{array}$ & $\begin{array}{r}0.481^{* *} \\
(0.097)\end{array}$ \\
\hline \multicolumn{5}{|c|}{ Foreign Borrowing } \\
\hline $\begin{array}{l}\text { Debt service on external debt, } \\
\text { total }\end{array}$ & $\begin{array}{r}-0.024^{* *} \\
(0.053) \\
\end{array}$ & $\begin{array}{r}-0.047^{* *} \\
(0.084) \\
\end{array}$ & $\begin{array}{l}-0.014 \\
(0.152) \\
\end{array}$ & $\begin{array}{r}0.056^{* * *} \\
(0.011) \\
\end{array}$ \\
\hline External debt stocks, total & $\begin{array}{r}-0.081^{* * *} \\
(0.015)\end{array}$ & $\begin{array}{r}-0.056^{* * *} \\
(0.021)\end{array}$ & $\begin{array}{r}-0.032^{* * *} \\
(0.011)\end{array}$ & $\begin{array}{r}0.053^{* *} \\
(0.081)\end{array}$ \\
\hline \multicolumn{5}{|c|}{ Capital Controls } \\
\hline $\mathrm{Ka}$ & $\begin{array}{r}0.342^{* *} \\
(0.072) \\
\end{array}$ & $\begin{array}{r}0.217 \\
(0.100) \\
\end{array}$ & $\begin{array}{r}0.325^{* *} \\
(0.073) \\
\end{array}$ & $\begin{array}{r}-0.319^{* *} \\
(0.072) \\
\end{array}$ \\
\hline Kai & $\begin{array}{r}0.324^{* *} \\
(0.071) \\
\end{array}$ & $\begin{array}{r}0.016 \\
(0.150)^{* * *} \\
\end{array}$ & $\begin{array}{r}0.057 \\
(0.082) \\
\end{array}$ & $\begin{array}{r}-0.014^{* * *} \\
(0.030) \\
\end{array}$ \\
\hline Kao & $\begin{array}{r}0.016 \\
(0.150) \\
\end{array}$ & $\begin{array}{r}0.019 \\
(0.251) \\
\end{array}$ & $\begin{array}{r}0.065^{* * *} \\
(0.041) \\
\end{array}$ & $\begin{array}{r}-3.683^{* * *} \\
(0.037) \\
\end{array}$ \\
\hline KAOPEN & $\begin{array}{r}0.047 * * * \\
(0.011) \\
\end{array}$ & $\begin{array}{r}0.170^{* *} \\
(0.059) \\
\end{array}$ & $\begin{array}{r}7.539 \\
(0.437) \\
\end{array}$ & $\begin{array}{r}-0.013^{* * *} \\
(0.017) \\
\end{array}$ \\
\hline
\end{tabular}

*** Significant at the 5\% confidence level; ** Significant at the $10 \%$ confidence level; Standard errors in parenthesis.

Source: author's calculations

The results of Table 7 show that after SS periods, there are positive coefficients of the variables of foreign exchange reserves and external debts on the variables, GDP, investment, and consumption and also a positive impact on unemployment. Consequently, the SS periods will lead to deterioration in macroeconomic conditions. This degradation is clearer by comparing these results with those of Table 6, before SS. These results are similar to the empirical literature about the impact of SS on the economy, and consequently, highlight the adverse effects of SS.

For the impact of the capital control indexes, there are positive and significant coefficients for a majority of these indexes (and negative for unemployment). These results show that the restrictive measures, applied after, SS support the macroeconomic aggregates. These controls have often been seen as a measure of financial stability and to hedge the economy against the unwanted effects of speculative capital flows. 


\section{Results and discussion}

The paper has specified and recognized periods of sudden stops for developing and developed economies to establish indexes of foreign exchange reserves, foreign borrowing, and capital inflows. The financial account of each country's balance of payments was used to collect data on gross capital inflow. These results show that the developing economies are the most resilient and show shorter sudden stops periods than those of the developed countries. Our results join those of Forbes and Warnock (2012) about the behavior of capital flows and the reaction of emerging countries to the reversal capital flow.

Contrarily, some coefficients of explanatory variables were not significant, this was the case for rates on global liquidity and long-term interest. This insignificance is not astonishing since historically the majority of capital inflow in developing economies has been in the form of FDI, which tends to be less sensitive to circumstances of the international finance and other types of investment notably portfolio investment (Espinoza, 2014).

The regression results show that countries with satisfactory foreign exchange reserves and also a low external debt burden are less faced by events of sudden stops. This finding is consistent with the results found in previous studies. Durdu et al (2009) find that the risk of a sudden stop is closely linked to the level of reserves accumulated by a country. Gourinchas and Obstfeld (2013) indicate that foreign exchange reserves play an important role to prevent financial crises, while Hur and Kondo (2016) suggest that the level of reserves is an indicator of predicting financial vulnerability.

The results of the study show that the spillover risk before the occurrence of a sudden stop is negligible for economies with correct policies for managing capital inflows, in particular with sufficient foreign exchange reserves, low foreign borrowing, and early capital controls. Fornaro (2019) confirms these observations, he shows that above all the application of capital controls is one of the essential factors to counter spillover risk. Overall, in an international context full of uncertainty, the monitoring of macroeconomic aggregates provides robust evidence on the importance of foreign exchange reserves to ease tensions on the financial markets of emerging countries.

An interesting role played by the foreign exchange reservesgives a kind of confidence to the resident investors and constitutes a kind of guarantee which prevents a fall or a stop in capital inflow (Mendoza, 2005). The economic impact of sudden stops is very significant. A decline in economic growth could reach $5 \%$ for an average economy following these international capital movements and/or a drop in capital inflows. These unfavorable movements of capital will cause a shortage in sources of financing, emerging countries will suffer following this shortage throughout periods of financial stress. 
The results of the study can also be interpreted under the impossible trinity concept (also known as the trilemma). For the past few decades, international macroeconomics has postulated the "Trilemma": with free capital mobility (absence of capital controls), independent monetary policies are feasible if and only if exchange rates are floating. Certainly, our study group these policies but consider the use of capital controls, that's why we don't examine the impacts of the three policies in a Trilemma framework. The results can also be interpreted in a broader or a limited Trilemma framework noted Quadrilemma and Dilemma. Firstly, the original Trilemma has morphed into a Quadrilemma, wherein financial stability has been added to the Trilemma's original policy goals (Aizenman, 2019). Our results highlight financial instability through the broad money of GDP variable (measured by M2 / GDP). The theoretical literature on financial crises usually uses this variable as a proxy for financial instability. Thus, our results can be also examined in the Quadrilemma. Secondly, the findings can be interpreted in a more reduced framework, the Dilemma. The global financial cycle transforms the trilemma into a "Dilemma" or an "irreconcilable duo": independent monetary policies are possible if and only if the capital account is managed (Rey, 2015). The main problem is to find an optimal policy for managing capital flows. The exchange rate policy (fixed or floating), as well as the liberalization of capital flows, have been grouped under an optimal policy for managing capital flows. The study results can be debated regarding the definition of an optimal policy for managing capital flows that will avoid sudden stops.

\section{Conclusions}

The models used in this study made it possible to draw some conclusions. The study highlights the great role of foreign exchange reserves which could serve as a shock absorber during crises, although it remains responsive to the scaling variable. The explanatory power of international reserves and its predictive role for sudden stops is interesting and the reserve / foreign borrowing ratio constitutes an adequate indicator of the international reserve.

The study results answered our three research hypotheses, by determining the periods of SS (H1) and highlighting the role of foreign exchange reserves and external debts to increase SS probability and also the role of inhibition of capital controls for this probability (H2). The study joins those who find negative impacts of SS on the macroeconomic aggregates (H3).

The paper emphasizes that countries accumulating foreign exchange reserves before the sudden stop have vigorously utilized them moreover for protecting the local currency from devaluation, to provide confidence in the country's ability to honor its financial commitments; and to provide funding assistance to local 
companies that have experienced severe constraints in obtaining credits (Mendoza, 2010). The empirical analysis has provided panel data proof where other elements were administrated to assess the strength of this result. The regressions estimations highlight the pro-cyclical character of capital flows and the fact that international variables are more interesting than endogenous-country factors to explain the capital outflows movements. The panel results have given proof that foreign exchange reserves are associated with a decline in inflows and with an increased willingness of resident investors to minimize the risks involved in repatriating investments during periods of global financial instability.

It is concluded that restrictive policies using capital control are not a lasting solution to cope with reversal capital and the recurrent manifestation of sudden stops. However, external debts show considerable dependence on controls so as not to resort to floating. If the sudden stop issue is not removed using dollarization, it would appear to have the advantage as a further market-oriented alternative for excellence. To have a total liberalization of capital account often requires independent management of exchange rate and monetary policy, as suggested by the impossible trinity or the incompatibility triangle.

Finally, the study gives a definition and a calculation of the events of SS as employed by previous studies. It will be interesting for a new study to conduct further research into sudden stops periods and to compare its results with those of previous studies. Likewise, total capital flows can include several types of flows other than those of this study. A new study may modify the calculation of total capital flows and consequently can obtain new results. Besides, our study chose to examine the consequences of SS on macroeconomic aggregates, a novel study can analyze the consequences of SS on the overall social well-being or income inequality.

\section{Acknowledgment}

The author is very thankful to all the associated personnel in any reference that contributed to/for this research.

\section{Conflict of Interest}

This research holds no conflict of interest.

\section{Funding}

This research did not receive any specific grant from funding agencies in the public, commercial, or not-for-profit sectors. 


\section{References}

Abidi, O., et al. (2018) "Firm-specific determinants of FDI from GCC to MENA countries", Journal of International Studies, 11(4), pp. 9-21, https://doi. org/10.14254/2071-8330.2018/11-4/1.

Aizenman, J. (2019) "International Reserves, Exchange Rates, and Monetary Policy: From the Trilemma to the Quadrilemma", In Oxford Research Encyclopedia of Economics and Finance. https://doi.org/10.1093/acrefore/ 9780190625979.013.313.

Agosin, M.R., et al. (2019) "Sudden stops of capital flows: Do foreign assets behave differently from foreign liabilities?", Journal of International Money and Finance, 96, pp. 28-36, https://doi.org/10.1016/j.jimonfin.2019.04.010.

Agosin, M.R., Huaita, F. (2012) "Overreaction in capital flows to emerging markets: Booms and sudden stops, Journal of International Money and Finance, 31(5), pp. 1140-1155, https://doi.org/10.1016/j.jimonfin.2011.12.015.

Aizenman, J., Lee, J. (2007) "International reserves: precautionary versus mercantilist views, theory and evidence", Open Economic Review, 18, pp. 191214, https://doi.org/10.1007/s11079-007-9030-z.

Alberola, E., et al. (2016) "International reserves and gross capital flows dynamics", Journal of International Money and Finance, 60, pp. 151-171, https://doi. org/10.2139/ssrn.2474609.

Alfaro, L., et al. (2004) "FDI and economic growth: the role of local financial markets", Journal of International Economics, 64, pp. 89-112, https://doi. org/10.2139/ssrn.305762.

Alfaro, L., et al. (2014) Sovereigns, upstream capital flows, and global imbalances. Journal of the European Economic Association, 12(5), pp. 1240 1284, https://doi.org/10.3386/w17396.

Alfaro, L., Kanczuk, F. (2009) "Optimal reserve management and sovereign debt", Journal of International Economics, 77(1), pp. 23-36, https://doi. org/10.1016/j.jinteco.2008.09.005.

Benigno, G. Fornaro, L. (2012) "Reserve accumulation, growth and financial crises". CEPR Discussion Paper. Nb. 9224. https://doi.org/10.1016/b978-0-12810402-6.00005-0.

Bianchi, J., et al. (2012) "International reserves and rollover risk". NBER Working Paper, 18628. https://doi.org/10.1257/aer.20140443.

Bilan, Y., et al. (2020) "Impact of Income Distribution on Social and Economic Well-Being of the State." Sustainability, 12(1), 429. https://doi.org/10.3390/ su12010429.

Bussiere, M., et al. (2013) "Capital Controls and Foreign Reserve Accumulation: Substitutes or Complements in the Global Financial Crisis?" Paris: French Bank, March. https://doi.org/10.24149/gwp119. 
Caballero, R., Panageas, S. (2005) "A quantitative model of sudden stops and external liquidity management”, NBER Working Paper. https://doi.org/10.3386/ w11293.

Calvo G.A., et al. (2006) "Relative price volatility under Sudden Stops: the relevance of balance sheet effects", Journal of International Economics, 69, pp. 231-54, https://doi.org/10.3386/w11492.

Calvo G.A., et al. (2008) "Systemic Sudden Stops: the relevance of balance-sheet effects and financial integration", NBER Working Paper, 14026. https://doi. org/10.3386/w14026.

Calvo, G.A. (1998) "Capital flows and capital-market crises: the simple economics of sudden stops", Journal of applied Economics, 1(1), pp. 35-54, https://doi.org /10.1080/15140326.1998.12040516.

Calvo G.A. (2002) "Globalization hazard and delayed reform in emerging markets", Economia 2(2):1-29. https:// doi.org/10.1353/eco.2002.0002.

Calvo, G.A., et al. (2006) "Sudden stops and phoenix miracles in emerging markets". American Economic Review, 96(2), pp. 405-410, https://doi. org/10.1257/000282806777211856.

Calvo, G.A., Reinhart, C.M. (1999) "When capital inflows come to a sudden stop: consequences and policy options".

Calvo, G.A., Talvi, E. (2005) "Sudden stop, financial factors and economic collapse in Latin America: learning from Argentina and Chile" (No. w11153). National Bureau of Economic Research. https://doi.org/10.3386/w11153.

Cardarelli, R., et al. (2010) "Capital inflows: Macroeconomic implications and policy responses”, Economic Systems, 34(4), pp. 333-356, https://doi.org/10.1016/j. ecosys.2010.01.004.

Chari, V.V. et al. (2005) "Sudden stops and output drops", American Economic Review, 95(2), pp. 381-387, https://doi.org/10.1257/000282805774670013.

Chinn, M.D., Ito, H. (2006) "What matters for financial development? Capital controls, institutions, and interactions", Journal of Development Economics, 81, pp. 163-192, https://doi.org/10.3386/w11370.

Cole, H.L., Kehoe, T.J. (2000) "Self-fulfilling debt crises", Review of Economic Studies, 67, pp. 91-116, https://doi.org/10.21034/sr.211.

Durdu, C.B., et al. (2009) "Precautionary demand for foreign assets in Sudden Stop economies: an assessment of the new mercantilism". Journal of Development Economics, 89, pp. 194-209, https://doi.org/10.2139/ssrn.1078924.

Edwards, S. (2004) "Financial openness, sudden stops, and current-account reversals", American Economic Review, 94(2), pp. 59-64, https://doi.org/ $10.1257 / 0002828041302217$.

Edwards, S. (2007) "Capital controls, capital flow contractions, and macroeconomic vulnerability". Journal of International Money and Finance, 26(5), pp. 814840, https://doi.org/10.1016/j.jimonfin.2007.04.010. 
Eichengreen, B., Gupta, P. (2016) "Managing sudden stops". The World Bank. https://doi.org/10.1596/1813-9450-7639.

Espinoza, R. (2014) "A model of external debt and international reserves". Cerdi. org, pp. 1-29, https://doi.org/10.1016/j.jimonfin.2007.04.010.

Fazaalloh, A. M. (2019) "Is Foreign Direct Investment Helpful to Reduce Income Inequality in Indonesia?". Economics \& Sociology, 12(3), p. 25, https://doi. org/10.14254/2071-789x.2019/12-3/2.

Fernández, A et al. (2016) "Capital control measures: A new dataset", IMF Economic Review, 64(3), pp. 548-574, https://doi.org/10.1057/imfer.2016.11.

Forbes, K.J., Warnock, F.E. (2012) "Capital flow waves: Surges, stops, flight, and retrenchment", Journal of international economics, 88(2), pp. 235-251, https:// doi.org/10.1016/j.jinteco.2012.03.006.

Fornaro, L. (2019) "Managing capital flows in the 21st century", International Finance, 22(3), pp. 439-446, https://10.1111/infi.12362.

Gourinchas, P. O., Jeanne, O. (2013) "Capital flows to developing countries: The allocation puzzle", Review of Economic Studies, 80(4), pp. 1484-1515, https:// doi.org/10.1093/restud/rdt004.

Gourinchas, P.O., Obstfeld, M. (2012) "Stories of the twentieth century for the twenty-first", American Economic Journal: Macroeconomics, 4(1), pp. 226-65. https://doi.org/10.1257/mac.4.1.226.

Guidotti, P.E. et al. (2004) “On the Consequences of Sudden Stops”, Economia, 4(2), pp. 171-214, https://doi.org/10.1353/eco.2004.0016.

Hawkins, J., Turner, P. (2000) "Managing foreign debt and liquidity risks in emerging economies: an overview", BIS Policy Papers, 8, pp. 3-60.

Hutchison, M.M., Noy, I. (2006) "Sudden stops and the Mexican wave: Currency crises, capital flow reversals and output loss in emerging markets", Journal of Development Economics, 79(1), pp. 225-248, https://doi.org/10.1016/j. jdeveco.2004.12.002.

Hur, S., Kondo, I.O. (2016) "A theory of rollover risk, sudden stops, and foreign reserves", Journal of International Economics, 103, pp. 44-63, https://doi. org/10.2139/ssrn.2243568.

Jeanne, O., Korinek, A. (2019) "Managing credit booms and busts: A Pigouvian taxation approach", Journal of Monetary Economics, 107, pp. 2-17, https://doi. org/10.1016/j.jmoneco.2018.12.005.

Kawai, M., Lamberte, M.B. (2010) "Managing capital flows: the search for a framework", Edward Elgar Publishing. https://doi.org/10.1080/00472336.2012. 634658.

Korinek A. (2011b) "The new economics of prudential capital controls", IMF Economic Review, 59, pp. 523-61, https://doi.org/10.1057/imfer.2011.19. 
Korinek, A., Mendoza, E.G., (2014) "From sudden stops to fisherian deflation: Quantitative theory and policy". https://doi.org/10.3386/w19362.

Mendoza E.G. (2005) "Real exchange rate volatility and the price of non-tradables in Sudden-Stop-prone economies", Economia, 6, pp. 103-48, https://doi. org/10.3386/w11691.

Mendoza, E.G. (2006) "Endogenous sudden stops in a business cycle model with collateral constraints: a Fisherian deflation of Tobin's Q" (No. w12564). National Bureau of Economic Research. https://doi.org/10.3386/w12564.

Mendoza, E.G. (2010) "Sudden stops, financial crises, and leverage", American Economic Review, 100(5), pp. 1941-66, https://doi.org/10.1257/aer.100.5.1941.

Ostry, J.D., (2012) "Managing Capital Flows: What Tools to Use?" Asian Development Review, 29(1), p. 82.

Ostry, J.D. et al. (2010) "Capital inflows: The role of controls", Revista de Economia Institucional, 12(23), pp.135-164, https://doi.org/10.3386/w17363.

Vasa, L., Angeloska, A. (2020) "Foreign direct investment in the Republic of Serbia: Correlation between foreign direct investments and the selected economic variables", Journal of International Studies, 13(1), pp. 170-183, https://doi:10.14254/2071-8330.2020/13-1/11.

Zehri, C. Abdelkarim, G.M., (2020) "Effectiveness of capital controls to reduce short term flows", International Journal of Innovation, Creativity and Change, Volume 11, Issue 12, pp. 235-262. 


\title{
Politike upravljanja naglim zastojima
}

\author{
Chokri Zehri ${ }^{1}$
}

\begin{abstract}
Sažetak
Upravljanje financijskim tokovima iziskuje odgovarajuću povezanost deviznih rezervi, inozemnog zaduživanja i kontrole kapitala. Ove politike smatraju se alatom za predviđanje naglih zastoja (SS). Stoga se u ovoj analizi utvrđuje pojavljivanje naglih zastoja / prekida financijskih tokova na uzorku od 200 zemalja u periodu od 1985. - 2019. godine. Vjerojatnost SS-a određuje se pomoću logit modela. Rezultati ukazuju na činjenicu da učinkovito upravljanje smanjuje vjerojatnost naglih zastoja. Provedena je analiza utjecaja rizika prelijevanja na bruto domaći proizvod, potrošnju, investicije i nezaposlenost. Rezultati pokazuju štetne utjecaje na ove makroekonomske varijable. Nalazi potvrđuju da zemlje sa zadovoljavajućom razinom deviznih rezervi, malim inozemnim zaduživanjem i koje započinju s kontrolom kapitala prije pojave naglih zastoja financijskih tokova manje pogađa rizik prelijevanja nego li gospodarstva u nastajanju koja su ranjivija od bogatih gospodarstava.
\end{abstract}

Ključne riječi: nagli zastoji, politike, tokovi kapitala, dugovi, rezerve, kontrole

JEL klasifikacija: F32, F36, F37

1 Docent, Prince Sattam Bin Abdulaziz University, College of Sciences and Humanities in AlSulail. Department of Business Administration, Saudijska Arabija. Znanstveni interes: međunarodna financijska liberalizacija, kontrola kapitala $i$ financijska kriza. Tel.: +966554907434; Fax: +966117822251.E-mail: c.alzhari@psau.edu.sa. 